Univerzitet u Beogradu
Poljoprivredni fakultet
Institut za poljoprivrednu tehniku
Naučni časopis
POLJOPRIVREDNA TEHNIKA
Godina XLVI
Broj 1, 2021.
Strane: $22-30$

UDK: 631.374; 629.551; 631-565

Original Scientific Paper

Originalni naučni rad

doi:10.5937/PoljTeh2101022T

\title{
EFFECT OF SOIL MOISTURE CONTENT, DYNAMIC LOAD AND WHEEL SLIPPAGE IN MEASURING TRACTION IN AN INDOOR TRACTION BED
}

\author{
A. F. Tola ${ }^{* 1}$, A.M Sedara ${ }^{1}$, O. B. Olatunde ${ }^{2}$ and A.A. Babalola ${ }^{2}$ \\ ${ }^{1}$ Agricultural Engineering Department, Federal University of Technology, \\ Akure, Nigeria \\ ${ }^{2}$ College of Engineering Olabisi Onabanjo, University Ibogun Campus, Nigeria
}

\begin{abstract}
A study was conducted to determine the effect of soil moisture content, dynamic load and wheel slippage in measuring traction. A single wheel test rig was developed to enable fundamental research on traction studies on tropical soil at the department of Agricultural and Environmental Engineering of Federal University of Technology, Akure. This facility consists of a moving carriage with a trolley that moves in either forward or reverse directions on rails well above a soil bin powered by $2.2 \mathrm{~kW}$, three phase induction motor. The present facility set up was able to operate in either towing test mode for tire motion resistance studies or driving test mode for tire net traction and tractive efficiency studies. The test tire on the moving carriage was powered to rotate by a motor with additional pull provided by a cable-pulley mechanism connected to a tower with hanging dead weights. All controls on the moving carriage were activated from the main control console. The developed facility was successfully tested to determine tractive efficiency for narrow wheels at a particular inflation pressure on clay soil. The single wheel test rig facility worked well and the research indicates that wheel load, wheel slippage, soil moisture content and inflation pressure has great effect on traction efficiency. Traction efficiency decreased as the wheel load and wheel slippage increased. The developed single wheel testing facility can perform traction tests in controlled soil conditions to study the effect of soil, tire and moisture parameters on the performance of the system.
\end{abstract}

Key words: Soil moisture content, dynamic load, wheel slippage, traction, inflation pressure

\footnotetext{
*Corresponding Author. Email address: Tol.akin@gmail.com
} 


\section{INTRODUCTION}

Traction is an important study in the behavior of tractive devices (wheels or tracks) in which pneumatic tire is for off road vehicles and hence the study of test rig for single wheel to study traction is of fundamental importance. Research studies indicate that about $20-55 \%$ of the energy developed to the drive tractor wheels is wasted on the tire soil interaction [1]. This energy is not only wasted but the resulting soil compaction created by a portion of this energy may be detrimental to crop production as well [2]. Due to the enormous problems of interaction between the vehicle's running gears (wheel, tract etc.) and various soil conditions and terrain surfaces, there have been rigorous research efforts to obtain a better understanding of traction studies. Tractive performance is influenced by tire parameters, soil condition etc. [3]. Traction properties of a wheel vehicle largely depend on the interaction between the wheel and the ground. Thus, it is essential to analyze this interaction with a view of attaining the best possible use of wheels and tracks under given conditions. The optimal use of a wheel (depending on a criterion we choose) consists of ensuring maximum efficiency of a wheel, not exceeding the permissible values of wheel slip, and obtaining the maximum tractive effort [4]. It is also noted that traction performance of tractors has been a challenging problem for many engineers especially in Nigeria.

More so, the globally increasing demand for food production magnifies the importance of crop yield of farmlands. Consequently, soil-tool interactions should be evaluated comprehensively to achieve this aim since crop yield is a function of farm condition. In the countries with mechanized agriculture, the intensive application of heavier tractors due to increasing farm operations endangers the soil condition of farm through all the forces applied to the ground. Determination of contact area between tire and soil plays an important role on both the intensity of soil compaction and also in the soil-wheel interactions [5]. Tests are conducted either on soil bin found in indoor testing facilities or by performing real field tire testing. Situations where the soil is brought to the tester, have been used to acquire a significant amount of data worldwide [6]

\section{Traction Parameters}

Five dimensionless parameters are used to describe tractive performance [7]:

i. Travel Reduction Ration (TRR), commonly called "slip" and expressed in percent.

ii. Net Traction Ration (NTR), sometimes called/weight ration.

iii. Tractive Efficiency (TE)

iv. Gross Traction Ration (GTR)

v. Motion Resistance Ration (MRR).

\section{Travel Reduction Ration (TRR)}

$$
T R R=1-\frac{\text { Actual Velocity }}{\text { Theoretical Velocity }}=1-\frac{V_{a}}{V_{t}}
$$


Travel reduction has traditionally been called "slip" or "\% slip", but technically this is incorrect. Slip occurs between surfaces.

\section{Net Traction Ration (NTR)}

$$
N T R=\frac{\text { Net } \text { Traction }}{\text { Dynamic reaction force }}=\frac{N T}{W d}
$$

The net traction ratio is sometimes referred to as pull/weight, P.W, dynamic traction ratio, or coefficient of traction. The dynamic reaction force of dynamic weight $(\mathrm{Wd})$ includes the effects of ballast and any weight transfer that may occur in the testing process

\section{Tractive Efficiency (TE)}

$$
\begin{aligned}
T E_{(\text {ratio })} & =\frac{\text { Output Power }}{\text { Input Power }}=\frac{N T \times V a}{\text { Axle Power }} \\
& =\frac{N T}{G T} \frac{V a}{V t}=\frac{N T / W d}{G T / W d} \frac{V_{a}}{V_{t}}=\left(\frac{N T R}{G T R}\right)\left(\frac{V_{a}}{V_{t}}\right)
\end{aligned}
$$

Tractive "inefficiency" is caused by both velocity losses and pull losses. The loss in travel speed is commonly referred to as "slip", although it is more accurately referred to as "travel reduction". Travel reduction is the result of the theoretical travel speed (Vt) not being entirely converted to forward progress ( $\mathrm{Va}$ ) due to losses within the soil, between the soil surface and the traction device and within the traction device (hysteresis and tire windup or belt slippage). Travel reduction losses are visible, that is, the operator can see it happening. The other component of tractive "inefficiency", which is less visible and often overlooked, is a loss of pull (net traction) when motion resistance reduced the amount of gross traction that is converted to useful output (net traction). This is part of what happens when a tractor is over ballasted. Travel reduction is reduced, but motion resistance is increased. Motion resistance losses are especially relevant to belts, as internal losses within the belt drive mechanism, rollers and bending of the belt are normally greater than those within a tire. On soft soils, the internal losses of belts are generally compensated for by lower external motion resistance than that of tires.

\section{Gross Traction Ration (GTR)}

$$
G T R=\frac{G T}{W_{d}}=\frac{T}{r t \times W_{d}}
$$

Gross traction (GT) is sometimes referred to as rim pull, design drawbar pull, or theoretical pull. It is the axle torque input converted to a pull force. It is the pull you would develop if there were no motion resistance loss. 
Gross traction (GT) itself cannot be measured directly and is usually calculated from the axle torque and radius of the wheel or tractive device. The problem is that the correct radius to use is not well defined or directly measurable.

There is no general agreement among traction researchers as to what radius to use and an alternate method of calculating gross traction ratio is preferred using energy or power considerations.

From the equations above

$$
G T R=\left(\frac{N T R}{T E}\right)\left(\frac{V_{a}}{V_{t}}\right)=\left(\frac{N T R}{T E}\right)(1-T R R)
$$

Having thus determined the gross traction ratio (GTR), since

$$
G T R=\frac{G T}{W_{d}}=\frac{T}{r t \times W_{d}}
$$

The effective torque radius ( $\mathrm{rt}$ ) can be calculated by:

$$
r t=\frac{T}{(G T R)(W d)}
$$

Motion Resistance Ratio (MRR)

$$
M R R=G T R-N T R
$$

The motion resistance ratio (MRR), sometimes referred to as rolling resistance, includes internal losses within the tractive device (for example, losses within a belt drive or a tire) and soil forces. All "force" losses beyond where the torque is measured are included in motion resistance, for example, gear losses if the torque is not measured directly at the input to the tractive device. An example of this might be use of input drive shaft torque when testing tires using a mechanical front wheel drive mechanism. Rolling losses of bogie wheels of a belt drive mechanism would be another example, as well as the torque required to overcome the bending of a belt.

\section{MATERIAL AND METHODS}

\section{Characteristics of the Soil that was studied}

The soil used for soil tire interaction in this research work was clay. The

\begin{tabular}{|c|c|}
\hline Characteristic & of the wheels tha \\
\hline Brand & IRC (INOUE RUB] \\
\hline Front/Rear & Front, rear \\
\hline Tire size - & $90 / 90-10$ \\
\hline Bias/Radial & Bias Ply \\
\hline Rim size- & 10 \\
\hline Tube/Tubeless & Tubeless \\
\hline
\end{tabular}
physical properties of clay are of extreme importance in soil science. The soil was gotten in Step B area of Federal University of Technology Akure. The soil was tested in the laboratory and confirmed to be clay. 


\section{Design of the Tool Carriage}

The tool carriage is fabricated using steel and is supported on four pairs of wheel mounting brackets.

The arrangement of the wheels were designed to run on the side railings of the soil bin.

The tool carriage and the soil processing carriage are placed on top of the soil bin for the operations. The tool carriage and soil processing carriage is pulled in either direction by means of rope. The rope is driven by the drive system positioned at one end of the bin. The bin provides rigid support for soil and the carriages. Tool carriage provides mounting and positioning for tools.

\section{Design of the Implement Carriage}

The implement carriage was fabricated using rectangular steel and is attached to the tool carriage. The carriage has a coupling recess to enhance the rigid coupling of the wheel. The function of the carriage is twofold;

For mounting traction devices such as traction or towed wheels for testing For mounting carriage subsystem which in turn carries the toolbar.

\section{Experiment conducted to investigate effect of wheel load and wheel slippage on Traction}

Load of various sizes $15,20,30$ and $40 \mathrm{~kg}$ were varied on the test rig to study the traction. Two conditions of wheel (inflation $380 \mathrm{kPa}$ and $276 \mathrm{kPa}$ ) were used to study its effect on traction and varying conditions of soil $10 \%$ and $8 \%$ moisture content respectively.

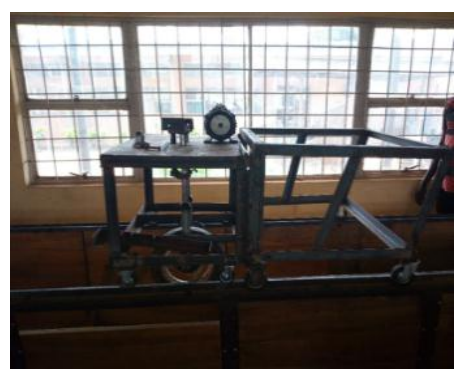

Fig. 1. Single wheel test rig

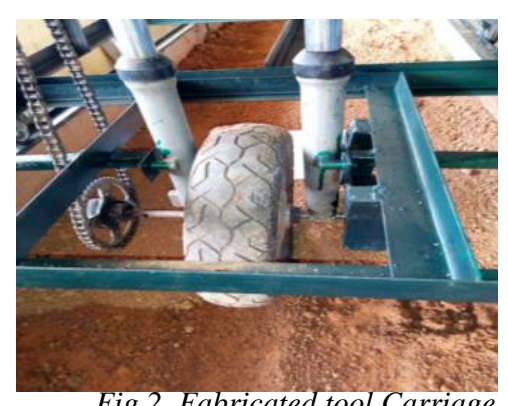

Fig.2. Fabricated tool Carriage

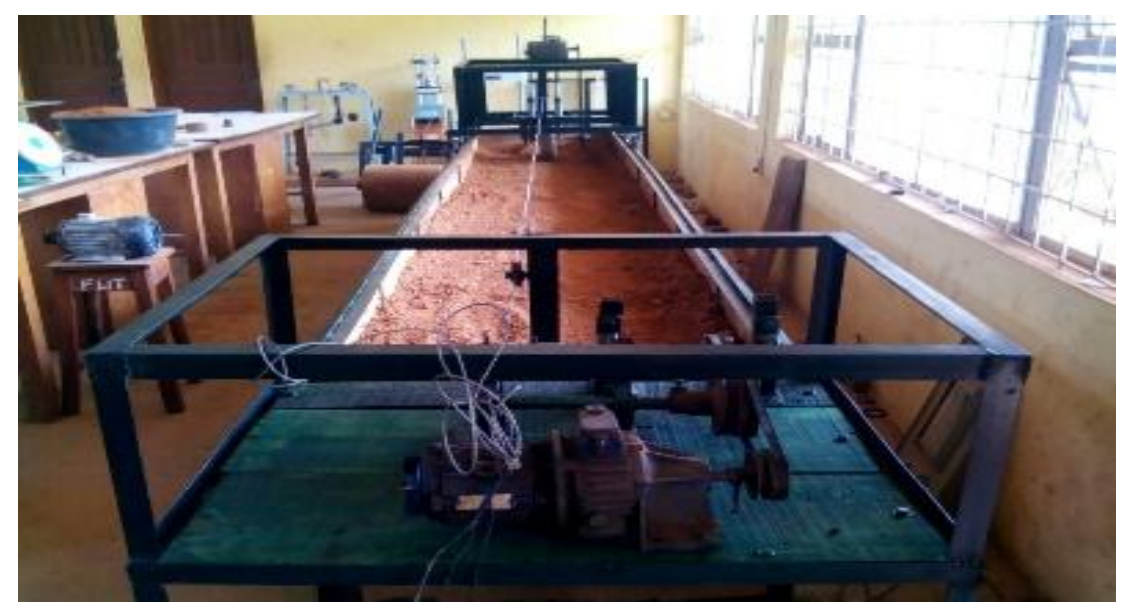

Fig.3. Fabricated single wheel test 


\section{RESULTS AND DISCUSSION}

The Preliminary tests indicated that the test rig facility worked well. The processing of the soil was carried out by a trolley powered by $2.2 \mathrm{~kW}, 3$ phase induction motor with reduction gear and the test rig was powered by another $2.2 \mathrm{~kW}, 3$ phase induction motor with reduction gear. The variables recorded for traction test were;

(i) Normal load on the wheel axle

(ii) Tire inflation pressure

(iii) Soil moisture content

(iv) Speed of the wheel

References should be numbered in brackets in the order of appearance in the text, e. g. [1], [3, 4], [7-11], etc. The full references should be listed at the end of the paper in numerical order of citation in the text.

All equations, formulas, and expressions should be numbered in parentheses e. $g$. (1), with right alignment, in the order of appearance in the text, and must be centered with one line left above and below.

\section{Result at inflation pressure of $380 \mathrm{kPa}$ and $8 \%$ moisture content}

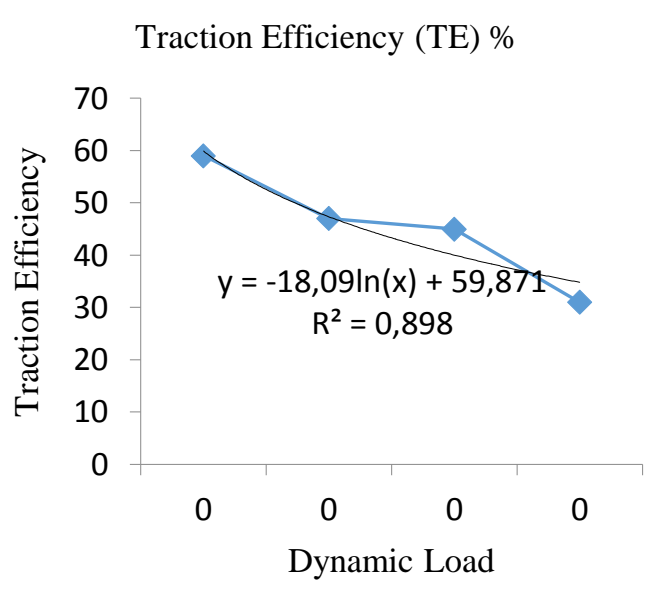

Fig. 4. Effect of slippage on tractive efficiency

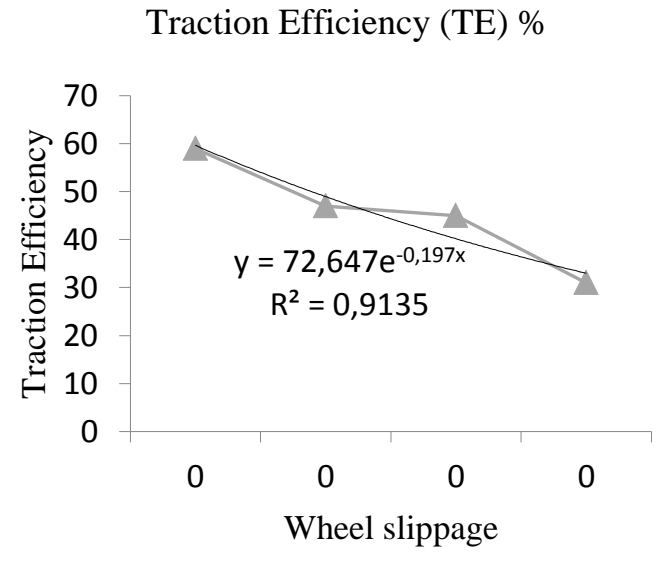

Fig.5. Effect of dynamic load on tractive efficiency

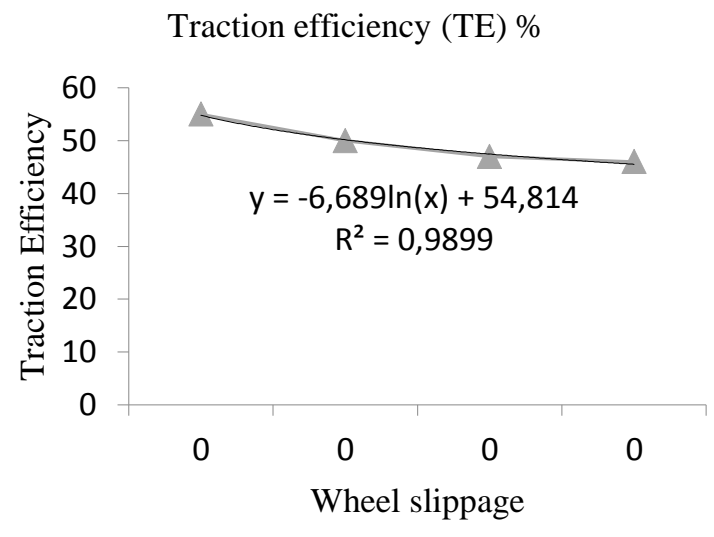

Fig. 6. Effect of wheel slippage on traction efficiency 


\section{Result At Inflation Pressure of 276 kPa, and $10 \%$ Moisture Content}

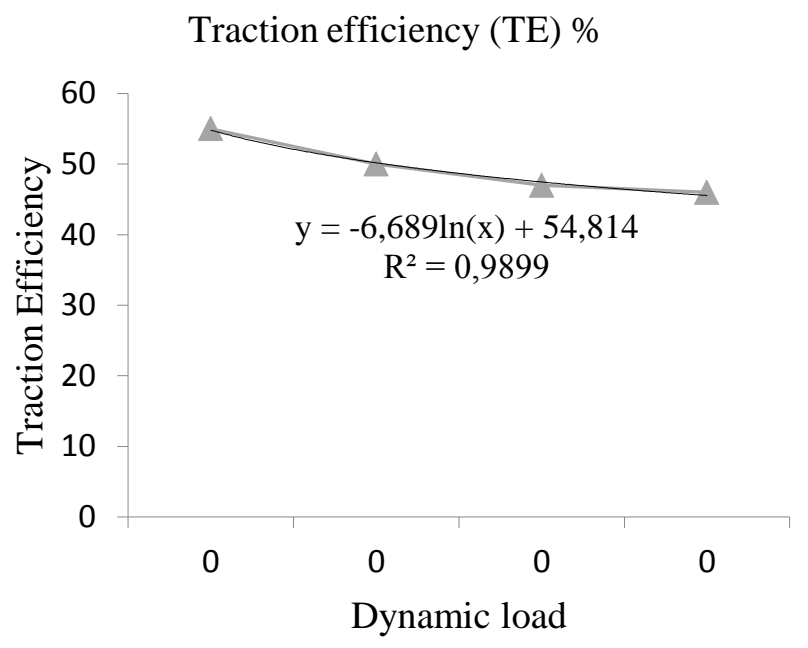

Fig. 7. Effect of dynamic load on traction performance

Figures 4 and 5 show the result at wheel inflation pressure of $380 \mathrm{kPa}$ and $8 \%$ moisture content.Traction efficiency decreases as wheel slippage and dynamic load increases.

Also, Figures 6 and 7 show the result at inflation pressure of $276 \mathrm{kPa}$ and $10 \%$ soil moisture content traction efficiency decreases as wheel slippage and dynamic load increases.

Similarly, reports concerned with tractive performance parameters in the literatures confirm the discovered trends in the investigations of [8],[9], and [10] respectively.

\section{CONCLUSIONS}

1. An indoor test rig for single wheel to study traction has been developed.

2. The developed single wheel testing facility is able to perform traction tests in controlled soil conditions to study the effect of soil, tire and system parameters on the performance of the tires.

3. The test rig has ease of maneuverability because of its simplicity in construction.

4. The developed test rig is a simple wheeled device, capable of testing of tires 500 $\mathrm{mm}$ in diameter and dynamic weight $400 \mathrm{~N}$.

\section{REFERENCES}

[1] Kumar AA, Tewari VK, Nare B (2016). Embedded digital draft force and wheel slip indicator for tillage research. Computers and Electronics in Agriculture, (127): pp. 38-49. 
[2] Yahya, A., Zohadie, M., Ahmad, D., Elwaleed, A. K., \& Kheiralla, A. F. (2007). UPM indoor tyre traction testing facility. Journal of Terramechanics, 44, 293-301. http://doi.org/10.1016/j.jterra.2007.03.002.

[3] Brixius, W. W. 1987. Traction prediction equations for bias-ply tires. ASAE Paper No. 871622. St. Joseph, Mich.: ASAE.

[4] Jerzy, Ż. (2010). Automation in Construction Traction efficiency of a wheeled tractor in construction operations, 19, pp, 100-108. http://doi.org/10.1016/j.autcon.2009.09.007

[5] Taghavifar H and Mardani A (2015): Net Reaction of a Driven Wheel as affected by slippage, velocity and Wheel load. J.of the Saudi Society of Ag. Sciences, 14: pp.167-171.

[6] Onwualu A.P. and K.C. Watts, (1989). Development of a soil bin test facility. ASAE Paper No. 89-1106, ASAE, St Joseph: Michigan.

[7] Zoz, F. and Grisso, R.D. 2003. Traction and Tractor Performance.Agricultural Equipment Technology Conference. ASAE PublicationNumber 913C0403. Louisville, KY.

[8] Taghavifar, H., Mardani, A., 2013. Investigating the effect of velocity, inflation pressure, and vertical load on rolling resistance of a radial ply tire. J. Terramechanics 50 (2), pp. 99-106.

[9] Pytka, J., Da browski, J., Zajacc, M., Tarkowski, P., 2006. Effects of reduced inflation pressure and vehicle loading on off-road traction and soil stress and deformation state. J. Terramechanics 43 (4), pp. 469-485.

[10] Degirmencioglu, A., Way, T.R., 2004. Tractive performance comparisons of radial-ply and bias-ply agricultural tractor drive tires. Agric. Engineering 10 (1-4), pp. 1-8.

\title{
UTICAJ SADRŽAJA VLAGE ZEMLJIŠTA, DINAMIČKOG OPTEREĆENJA, KLIZANJA TOČKOVA KOD ODREĐIVANJA SILE VUČE U USLOVIMA LABORATORIJE
}

\author{
A. F. Tola ${ }^{1}$, A.M Sedara ${ }^{1}$, O. B. Olatunde ${ }^{2}$ and A.A. Babalola ${ }^{2}$ \\ ${ }^{1}$ Agricultural Engineering Department, Federal University of Technology, \\ Akure, Nigeria \\ ${ }^{2}$ College of Engineering Olabisi Onabanjo. University Ibogun Campus, Nigeria
}

Sažetak: Studija je urađena kako bi se utvrdio uticaj sadržaja vlage u zemljištu, dinamičkog opterećenja i proklizavanja točkova na merenje sile vuče.

Ispitni uređaj sa jednim točkom razvijen je kako bi se omogućilo osnovno istraživanje studija vuče na tropskom zemljištu na Odeljenju za poljoprivredno inženjerstvo i zaštitu životne sredine federalnog Tehnološkog Univerziteta, Akure, Nigerija.

Ovaj uređaj ima pokretna kolica koja se kreću u pravcu napred ili unazad na šinama iznad posude (kade) sa uzorkom zemljišta.

Kolica dobijaju pogon od trofaznog asinhronog motora snage od 2,2 kW. Sadašnje postavljeno postrojenje može da radi u bilo kojem režimu ispitivanja vuče za studije otpora kretanja pneumatika ili u ispitivanja režima kretanja za studije vuče i efikasnosti točkova uređaja.

Testiran točak (pneumatik) na pokretnim kolicima dobija pogon preko remenice i povezan je sa dodatnim mehanizmom za moguću promenu vertikalnog opterećenja sa tegovima.

Sve komande na pokretnim kolicima aktiviraju se sa glavne kontrolne konzole. 
Razvijeno postrojenje (uređaj) u laboratoriji uspešno je testirano za utvrđivanje vrednosti vučne sile uskih tipova točkova pri određenom pritisku u pneumatiku za uslove glinovitih tipova zemljišta.

Postrojenje u laboratorijskim uslovima za ispitivanje sa jednim točkom je dobro funkcionisalo i istraživanje pokazuje da opterećenje točkova, proklizavanje točkova, sadržaj vlage u zemljištu i pritisak u pneumatiku, imaju veliki uticaj na vrednost sile vuče. Efikasnost sile vuče se smanjivala kako se povećavalo opterećenje točkova i klizanje točkova.

Razvijeno laboratorijsko postrojenje za ispitivanje sa jednim točkom može da simulira testove vuče u kontrolisanim uslovima zemljišta kako bi se proučio uticaj različitih parametara zemljišta, pneumatika i vlage na performanse sistema.

Ključne reči: sadržaj vlage u zemljištu, dinamičko opterećenje, proklizavanje točkova, vuča, pritisak u pneumatiku

Prijavljen:

Submitted: 11.06.2020.

Ispravljen:

Revised: 20.11.2020.

Prihvaćen:

Accepted: 22.02.2021. 